\title{
In Praise of Fragments: A Manuscript of the Prose Tristan in Châlons-en-Champagne
}

The work today known as the prose Tristan, whose earliest version was composed c. 1220-1235, was one of the most widely disseminated literary texts in French of the later Middle Ages. ${ }^{1}$ Of the 80-plus medieval manuscripts that have come down to us, however, only ten volumes or sets of volumes can be considered "complete" insofar as they tell a more or less uninterrupted tale from prologue to epilogue. ${ }^{2}$ Most of the surviving manuscripts, though materially intact, provide only one or two sections of this vast text, or else a selection of choice episodes. And approximately one quarter of the manuscripts listed in the most up-to-date inventories of Tristan manuscripts are fragments. To use the words of A. C. Dionisotti, these fragments were "made rather than born" thus: they were physically detached from more complete volumes some time after their production, sometimes by accident or through wear and tear, but more often than not because later users prized the durability of parchment over the text written upon it when it came to binding their printed books or even lining their hats. ${ }^{3}$

Though most of the known Tristan fragments have been described and edited by scholars in journal articles much like this one, they have garnered little attention. For sound reasons, they were largely overlooked by the Tristan's modern editors, who assessed manuscripts on the basis of date, version, quality and, moreover, completeness. For her edition of the first part of the roman (corresponding to $\S 1$ 1-91 of Løseth's Analyse), Renée Curtis selected Carpentras, Bibliothèque municipale, 404 as base manuscript, having determined that it was the most complete member of the most primitive family of manuscripts. When it came to editing the narrative of Tristan's double imprisonment ( $\$ 282-319)$, Joël Blanchard opted for Paris, Bibliothèque nationale de France, fonds français, 772 on the basis of its early date and relative material completeness for the episode in question. And for the two collaborative editions directed by Philippe Ménard, Vienna, Österreichische Nationalbibliothek, 2542 was selected as the only complete thirteenth-century representative of "Version II" (the so-called "Vulgate" text), and BnF, f. fr. 757 as the only complete witness of "Version I." Understandably enough, only a

\footnotetext{
${ }^{1}$ For a cogent discussion of the date of the earliest version of the prose Tristan, see Emmanuèle Baumgartner, Le «Tristan en prose» : essai d'interprétation d'un roman médiéval (Geneva: Droz, 1975), 36-52. The terminus a quo for the Tristan is supplied by the Lancelot-Grail Cycle, which was known to the author(s) of the Tristan in its entirety. A case has been made for the existence of a cyclic version of the Lancelot-Grail by the early 1220 s, which would necessitate a similar adjustment to the date range of $c$. 1230-1235 that is usually given for the Tristan: see Alison Stones, “The Earliest Illustrated Prose Lancelot Manuscript," Reading Medieval Studies 3 (1977).

${ }^{2}$ Chantilly, Bibliothèque du Château, 645-647; the two-volume set formed by Chantilly, Bibl. du Château, 648 and Dijon, Bibliothèque municipale, 527; Paris, Bibliothèque nationale de France, fonds français, 97; BnF, f. fr. 99; BnF, f. fr. 100-101; BnF, f. fr. 335-336; BnF, f. fr. 756-757; Vienna, Österreichische Nationalbibliothek, 2537; ÖNB 2539-40; ÖNB 2542.

${ }^{3}$ A. C. Dionisotti, "On Fragments in Classical Scholarship," in Collecting Fragments = Fragmente sammeln, ed. Glenn W. Most (Göttingen: Vandenhoeck \& Ruprecht, 1997), 1.
} 
handful of the most important (read: complete) manuscripts are included in the varia lectio of these editions. ${ }^{4}$

Any attempt to pinpoint the place of a single witness within a manuscript tradition as complex as that of the prose Tristan is likely to be a tricky business. In the case of the prose Tristan, such efforts are complicated by the lack of a universally accepted classificatory schema (let alone a critical edition). At the very least, scholars must work with the two principal "versions" identified by Løseth, the four "versions" later recognized by Baumgartner, the various "families" of manuscripts delineated by Curtis for the first part of the roman, as well as the affiliations between codices noted by the numerous contributors to the edition of Version II. ${ }^{5}$ All four of these classifications are partial in their own way, taking into account either a limited portion of the text, a limited number of codices, or both. It goes without saying that none of them was drawn up with fragments in mind.

Pinpointing the place of a fragment within a manuscript tradition like that of the Tristan can be particularly tricky. Because Løseth and Baumgartner sorted manuscripts chiefly on the basis of larger-scale narrative units, their classifications are of limited use for fragments, which may only preserve a fraction of one of Løseth's paragraphs. The manuscript affiliations described by Curtis and Ménard et al., meanwhile, provide a sensible starting-point, but they, too, are of

\footnotetext{
${ }^{4}$ Section numbers are given in parenthesis according to E. Löseth, Le Roman de Tristan, le Roman de Palamède et la Compilation de Rusticien de Pise : analyse critique d'après les mansucrits de Paris (Paris: Bouillon, 1891). The major modern editions of the Tristan are as follows: Le Roman de Tristan en prose, ed. Renée L. Curtis, 3 vols (Munich: Max Hueber, 1963; Leiden: Brill, 1976; Cambridge: Brewer, 1985); Le Roman de Tristan en prose : les deux captivités de Tristan, ed. Joël Blanchard (Paris: Klincksieck, 1976); Le Roman de Tristan en prose, ed. Philippe Ménard et al., 9 vols (Geneva: Droz, 1987-1997); and Le Roman de Tristan en prose : version du manuscrit fr. 757 de la Bibliothèque nationale de Paris, ed. Philippe Ménard et al., 5 vols (Geneva: Slatkine, 1997-2007). Transcriptions of Tristan fragments are given in Wolfram von Zingerle, "Ein Tristan-Fragment in Tirol," Romanische Forschungen 10 (1899); Mario Pelaez, "Un frammento del romanzo francese in prosa di Tristano," Studi medievali 2 (1929); Jean Séguy, "Fragments mutilés du Roman de Tristan en prose," Bulletin bibliographique de la Société internationale arthurienne [hereafter BBSIA] 5 (1953); Hiram Peri, "Épisodes inédits du Roman de Tristan (manuscrit de Jérusalem) avec deux nouveaux lais de Tristan," Scripta Hierosolymitana 2 (1955); Fanni Bogdanow, "Un nouveau fragment du roman de Tristan en prose," Romania 80 (1959); Philip Bennett, "L'importance des fragments pour l'établissement des traditions manuscrites : une étude du fragment du Tristan en prose d'Exeter," Romania 95 (1974); Monica Longobardi, "Dall'Archivio di Stato di Bologna alla Biblioteca Comunale dell'Archiginnasio: resti del Tristan en prose e de Les Prophécies de Merlin," Studi mediolatini e volgari [hereafter SMV] 39 (1993); Marie-Luce Chênerie, "Étude et édition des fragments du Tristan en prose de Toulouse," BBSIA 50 (1998); Roberto Benedetti, "Un frammento del Roman de Tristan en prose: fra tradizione toscana e tradizione veneta (Udine, Archivio di Stato, fr. 110)," SMV 49 (2003); Anna Radaelli, "Il testo del frammento Vb2 del Roman de Tristan en prose (Biblioteca Apostolica Vaticana, Vat. Lat. 14740)," SMV 50 (2004); Françoise Vielliard, "Les fragments du Tristan en prose de Poitiers : Arch. départ. de la Vienne, pièce 13," in Des Tristan en vers au Tristan en prose : hommage à Emmanuèle Baumgartner, ed. Laurence Harf-Lancner et al. (Paris: Champion, 2009); and Damien de Carné and Yan Greub, "Le fragment de Nancy du Tristan en prose," Romania 131 (2013).

${ }^{5}$ In addition to the introductions to the volumes edited by Curtis and Ménard et al., see Löseth, Analyse critique, xiixiii, and Baumgartner, Essai d'interprétation, 85-87.
} 
limited use unless the fragment in question happens to preserve a section of the text edited by Curtis, or turns out to be closely related to the manuscripts collated by Ménard et al.

Our forebears may have chopped them up for their bindings and hats, and modern editors and classifiers may not have given them much thought, but we would do well to persevere in the tricky business of placing fragments within their wider textual traditions. Previous editors of fragments of the prose Tristan have justified their endeavours in one of two ways. Some have drawn on fragments to refine our understanding of when and where the Tristan circulated. ${ }^{6}$ Others, meanwhile, have focused on the form that the prose Tristan took in transmission, aiming to reassess the prevalence of different versions of the text and the extent of their medieval dissemination. $^{7}$

In presenting the fragment of the prose Tristan today in the Archives départementales de la Marne (under the shelfmark 3.J.141), it is chiefly to the second of these aims that I subscribe. The fragment in question was first mentioned in a contribution to Romania by Charles Samaran published in $1955 .{ }^{8}$ Samaran gave brief notices of four sets of fragments that had recently been discovered in the Archives, limiting his discussion of the Tristan fragment to basic physical description and identification of the particular chapter that it preserved. None of the later editors of the Tristan makes reference to the fragment, and it has been classified only recently, and tentatively at that, as a witness of Version II. ${ }^{9}$ The Châlons fragment will be edited here for the first time, and its contribution to our understanding of the Tristan's medieval circulation duly noted. In attempting to determine the place of this fragment within the wider manuscript tradition, however, I shall also draw attention to a methodological issue faced by classifiers of Tristan manuscripts, and of fragments in particular.

\section{Physical description and provenance}

The Châlons fragment of the Tristan comprises a single bifolium, taken from the centre of a gathering. The two leaves, made of high-quality parchment and each measuring c. 368 x 295mm,

\footnotetext{
${ }^{6}$ Editors of Tristan fragments, for example, have drawn attention to circulation in the Occitan-speaking zone (Séguy, "Fragments mutilés," 85-86), Lorraine (De Carné and Greub, "Fragment de Nancy," 200), and the Veneto (Benedetti, "Frammento del Roman de Tristan," 47-48).

${ }^{7}$ Bogdanow, for example, cites the rarity of Version I to justify her edition of the fragment in the Biblioteca Angelica ("Nouveau fragment," 516). With her edition and study of a fragment in the Biblioteca Apostolica Vaticana, meanwhile, Radaelli seeks to shed light on the transmission of the Tristan in Italy ("Testo del frammento," 185), drawing attention, for instance, to the presence of both Versions I and II in an Italian scriptorium (ibid., 205).

${ }^{8}$ Charles Samaran, "Fragments de manuscrits," Romania 76 (1955): 242.

${ }^{9}$ Fabrizio Cigni, "Per un riesame della tradizione del Tristan in prosa, con nuove osservazioni sul ms. Paris, BnF, fr. 756-757," in Culture, livelli di cultura e ambienti nel Medioevo occidentale: Atti del IX Convegno della Società Italiana di Filologia Romanza (S.I.F.R.), Bologna, 5-8 ottobre 2009, ed. Francesco Benozzo (Rome: Aracne, 2012), 264.
} 
must once have belonged to a large and handsome volume. The justification $(308 \times 205 \mathrm{~mm})$ is marked in brown ink, forming two columns of 48 lines. Paragraphs begin with pen-flourished initials, alternating red and blue (with decoration in the contrasting colour). The scribe wrote in a meticulously copied northern textualis in ink that today appears brown. He preferred box-a to a with a double bow (the latter rarely employed), often bifurcated his ascenders, consistently ticked $\mathbf{i}$ and dotted $\mathbf{y}$, used a round $\mathbf{s}$ in final position with a lower compartment set slightly to the right of the upper one, hung a vertical hairline from the crossbar of $\mathbf{t}$ in final position, and employed a " $b$ "-shaped $\mathbf{v}$ in initial position. Abbreviation is extremely scarce, and generally limited to the end of the line. Though the hand could perhaps date to the fourteenth century, as Samaran suggested ("Fragments de manuscrits," 242), a date of production in the first part of the fifteenth century also seems plausible.

To judge by a title added on fol. $1^{\mathrm{r}}$ (Registre des baulx à ferme des heritages appartenant à la fabrique de $N$. dame et autres Marchés), the bifolium served as a document wrapper during the seventeenth century. This accounts for the fragment's poor condition. It has been cropped, its edges folded and the external corners of fol. 2 cut off. There are two holes in the upper part of the outer column of fol. 1, in addition to the large hole in the inner column of fol. 2 and the smaller hole in the outer one. The text on the outer pages, moreover, is so worn as to be scarcely legible in places.

The "N. dame" mentioned on fol. $1^{\mathrm{r}}$ is no doubt Notre-Dame-en-Vaux in Châlons itself. This collegiate church, served by six and later ten canons, is reputed to have possessed a well-stocked library until the demolition of its cloister in the eighteenth century. There is no trace, however, of a prose Tristan in any of the inventories made during the sixteenth century. ${ }^{10}$ Claude-Rémi Buirette de Verrières noted in 1788 that the Notre-Dame "fabrique," the lay body responsible for the upkeep of the church, had become "singulierement riche" ("remarkably wealth") thanks to donations by the local gentry. ${ }^{11}$ Might the manuscript from which the Châlons fragment was taken have constituted one such donation? Copies of Chrétien's romans and of the LancelotGrail Cycle were made in significant numbers in Champagne during the thirteenth century, but there is also evidence that Arthurian material piqued the interest of the upper echelons of Champenois society during the fifteenth century: Cologny, Fondation Martin Bodmer, 105, for example, a four-volume Lancelot-Grail Cycle of the fifteenth century, bears the arms of Guyot le

\footnotetext{
${ }^{10}$ On the library at Notre-Dame-en-Vaux, see Maxence Hermant, "Enlumineurs et commanditaires à Châlons et à Reims au XVe siècle," in Très riches heures de Champagne : l'enluminure en Champagne à la fin du moyen âge, ed. François Avril, Maxence Hermant, and Françoise Bibolet (Paris: Hazan, 2007), 60. The sixteenth-century inventories of Notre-Dame-en-Vaux are published in Édouard de Barthélemy, ed., "Inventaire du mobilier de l'église de Notre-Dame-en-Vaux, de Châlons-sur-Marne, dressé en 1526," Revue des Sociétés savantes des départements 2 (1880).

${ }^{11}$ M. Buirette de Verrierres, Annales historiques de la ville et comté-pairie de Châlons-sur-Marne (Châlons-enChampagne: Seneuse, 1788), clxviii.
} 
Peley of Troyes. ${ }^{12}$ Given the importance of Notre-Dame as a pilgrimage destination, howeverits Holy Umbilical Cord was especially effective, it would seem, at inspiring largesse - a gift to the "fabrique" from further afield is also perfectly plausible.

\section{Textual affiliation}

The fragment begins with Galaad, Claudin and Angenés en route to the kingdom of Sorelois, not at Løseth’s §448, as Samaran wrote ("Fragments de manuscrits," 242), but part-way through $\S 447$. The knights encounter Tristan and Palamedés, and before long the two parties have challenged each other to a jousting match. When it comes to allocating partners, Galaad is a model of diplomacy, while Tristan and Palamedés argue over who should fight Claudin. Tristan has his way, and before long Claudin is lying on the ground, his helmet torn off, pursued by Tristan brandishing a sword. It is Galaad's duty to intervene: how could Tristan attack an unarmed knight? Would he not prefer to measure himself against another opponent (i.e. Galaad himself)?

In §448, Galaad gains the upper hand against Tristan, and Palamedés against Angenés. Seeing that Tristan is struggling, Palamedés launches himself at Galaad, despite the latter's protestations. Tristan turns his attentions instead to Angenés, soon leaving him languishing beside a tree. Palamedés and Tristan then squabble over whose turn it is to fight Galaad next, prompting Galaad to ask, "estes vous chevaliers errans?" (“are you really knights-errant?”). Such tactics of swapping partners to "rest" while fighting a weaker opponent are hardly becoming of proper knights, Galaad claims; he would much rather defeat them one by one, starting with the most self-assured of them (cue more bickering).

Tristan fancies his chances most and performs better against Galaad this time. He is on the cusp of defeat, however, when the fight is interrupted by the arrival of the maiden who rescued Galaad from Brehus's prison (recounted in §445). She wishes to claim the reward that Galaad had promised her without further delay. The fragment ends, towards the close of $\$ 448$, with Galaad's protestations: he must be granted leave by his opponent before he can attend to the maiden. This, then, is a scene that brings the rivalry between Tristan and Palamedés to the fore, as well as recognizing Galaad as chief upholder of the chivalric code of conduct.

\footnotetext{
${ }^{12}$ On the place of production of manuscripts preserving the romans of Chrétien de Troyes, see Terry Nixon, "Catalogue of Manuscripts," in Les Manuscrits de Chrétien de Troyes = The Manuscripts of Chrétien de Troyes, ed. Keith Busby et al. (Amsterdam: Rodopi, 1993), II, 15-16. For manuscripts of the Lancelot-Grail Cycle, see Alison Stones, "Chronological and Geographical Distribution of Lancelot-Grail Manuscripts," Lancelot-Graal Project (2010), accessed May 8, 2015, http://www.lancelot-project.pitt.edu/LG-web/Arthur-LG-ChronGeog.html. For a description of Bodmer 105, see Françoise Vielliard, Manuscrits français du moyen âge (Cologny: Fondation Martin Bodmer, 1975), 67-71. Lastly, on the renewal of manuscript production in Troyes, Reims and Châlons during the fifteenth century, see Avril, Hermant and Bibolet (eds), Très riches heures.
} 
The encounter between the five knights preserved by the Châlons fragment is present without major variation in both of the versions recognized by Løseth (Analyse critique, 306-7) and in all four versions identified by Baumgartner (Essai d'interprétation, 53-87). Curtis's stemma, meanwhile, cannot be expected to be relevant for this episode, which occurs long after the section she edited. As for the varia lectio of the Ménard edition of Version II, only three variant readings concerning a handful of manuscripts are given for this passage (Roman de Tristan, VII, 457). How, then, do we go about classifying the Châlons fragment?

We might begin by comparing a paragraph of our fragment, transcribed diplomatically, to the relevant passages in the modern editions of Versions I and II:

\begin{tabular}{|c|c|c|}
\hline Châlons & $\begin{array}{c}\text { Version I } \\
\text { (Ménard et al., IV, 406) }\end{array}$ & $\begin{array}{c}\text { Version II } \\
\text { (Ménard et al., VII, 228) }\end{array}$ \\
\hline $\begin{array}{l}\text { [fol. } \mathbf{2}^{\text {ra }} \text { ] Lors se trait tristram } \\
\text { auant et dist si / hault que } \\
\text { palamedes lentent moult / } \\
\text { bien palamedes se dieux me } \\
\text { doint bonne auan / ture quant } \\
\text { ie plus regarde vostre affaire } \\
\text { et ie / plus voy folie en vous . } \\
\text { Or me dittes se dieux / vous } \\
\text { gart quant vous de ceste } \\
\text { bataille me / feistes departir } \\
\text { auies vous greigneur } \\
\text { e[spera]n- / ce en vostre } \\
\text { cheualerie que en la mie[nne] } \\
\text { [cert]es / ie me merueille de } \\
\text { vous . Or me [laisses ester] / } \\
\text { ce dist palamedes . que ie } \\
\text { croy quil [ne]nporte- / ra } \\
\text { gueres du mien . palamedes } \\
\text { fut trop cour- / roucies quant } \\
\text { il vist que tristram auoit en / } \\
\text { telle maniere parle alui . Car il } \\
\text { lui est bien / auis que tristram } \\
\text { vueille dire quil est oul- / tres }\end{array}$ & $\begin{array}{l}\text { Lors se tret avant et dit, si qe } \\
\text { Palamedés l'entent tout } \\
\text { clerement, 'Palamedés,' ce dit } \\
\text { Tristan, 'se Dieux me doint } \\
\text { bone aventure, quant je plus } \\
\text { regart votre afere et plus truis } \\
\text { folie en vous! Or me dites, se } \\
\text { Diex vos saut, quant vos de } \\
\text { ceste bactaille me feïstes } \\
\text { orendroit departir, aviez vos } \\
\text { greignor esperance de vostre } \\
\text { chevalerie qe de la moie? } \\
\text { Certes, je me mervoill de vos! } \\
\text { Laissiéz moi, beau sire, cest } \\
\text { fet, q'il m'est avis q'il ne me } \\
\text { grevera mie tant come il fet a } \\
\text { vos.' De ceste paroles est } \\
\text { vergongneux Palamedés } \\
\text { estrangement, car il li est avis } \\
\text { qe Tristan vielt dire q'il soit } \\
\text { oultré. }\end{array}$ & $\begin{array}{l}\text { Lors se traist mesire Tristrans } \\
\text { avant et dist si haut que } \\
\text { Palamidés l'entent bien: } \\
\text { 'Palamidés, se Diex me doint } \\
\text { boine aventure, quant je plus } \\
\text { regart vostre afaire, et je plus } \\
\text { truis folie en vous. Or me dites, } \\
\text { se Diex vous saut, quant vous } \\
\text { de ceste bataille me feïstes } \\
\underline{\text { departir, aviés vous greigneur }} \\
\text { esperance de vostre cevalerie } \\
\text { que de la moie? Certes, jou me } \\
\text { merveil de vous. Laissiés moi, } \\
\text { biaus sire, cest fait, qu'il m'est } \\
\text { avis qu'il ne me grevera noient } \\
\text { tant com il fait a vous.' De } \\
\text { ceste parole est vergoigneus } \\
\text { Palamidés estrangement, car il } \\
\text { li est bien avis que mesire } \\
\text { Tristrans voelle dire qu'il soit } \\
\text { outrés }\end{array}$ \\
\hline
\end{tabular}

A preliminary comparison of this kind suggests that the Châlons fragment bears a slightly closer resemblance to Version II than to Version I. The results, however, are hardly conclusive.

A next step would be to compare the fragment to the "mixed" or "interpolated" versions that Baumgartner labelled "III" and "IV". Perhaps surprisingly, this step has not always been taken 
with regards to Tristan manuscripts. Partly because scholars have traditionally been more interested in the differences between Versions I and II, partly because Versions III and IV draw more heavily on Version II than they do on Version I, and partly no doubt because of the catchall status of the term "Vulgate" attached to Version II, several non-Version I manuscripts have been presumed in scholarship to be copies of Version II. Three manuscripts deemed Version II by Baumgartner (Essai d'interprétation, 85), for example, are now known to preserve Version III, at least in part, and a further codex that has previously been classified as Version II has recently been found to combine both Versions III and IV. ${ }^{13}$ If we compare the same paragraph of the Châlons fragment to the relevant passages in representatives of Versions III and IV, transcribed diplomatically below, it is apparent that a further manuscript can be added to the Version IV list:

\begin{tabular}{|c|c|c|}
\hline Châlons & $\begin{array}{c}\text { Version III } \\
\text { (BnF, f. fr. 772) }\end{array}$ & $\begin{array}{c}\text { Version IV } \\
\text { (BnF, f. fr. 99) }\end{array}$ \\
\hline 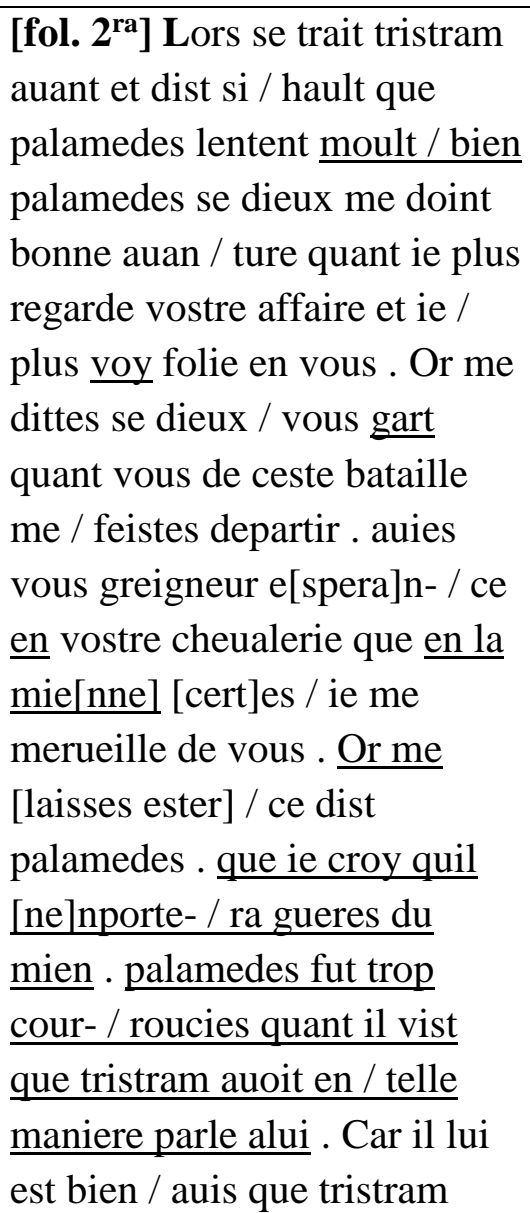 & $\begin{array}{l}\text { [fol. 267 }{ }^{\text {ra }} \text { ] Lors se trait tristan } \\
\text { auant } \text { et dist si haut / que } \\
\text { Palamedes lentent bien . } \\
\text { Palamedes / se dex me doint } \\
\text { bone auenture quant ie plus / } \\
\text { resgart vostre afaire et ie plus } \\
\text { truis folie / en uous . Or me } \\
\text { dites se dex vous saut quant / } \\
\text { vous de ceste bataille me } \\
\text { feistes de partir a / viez vous } \\
\text { greignor esperance de vostre } \\
\text { che / valerie que de la moie } \\
\text { certes ie me meruoil / de uous } \\
\text { lessiez moi biau sire cest fait } \\
\text { quil / [fol. 267rb] mest auis } \\
\text { quil ne me greuera noiant . Ne } \\
\text { / tant con il fet auous de ceste } \\
\text { parole est ver / gondeus } \\
\text { palamedes estrangement. car } \\
\text { il / li est bien auis que tristan } \\
\text { voille dire quil / soit oultrez }\end{array}$ & 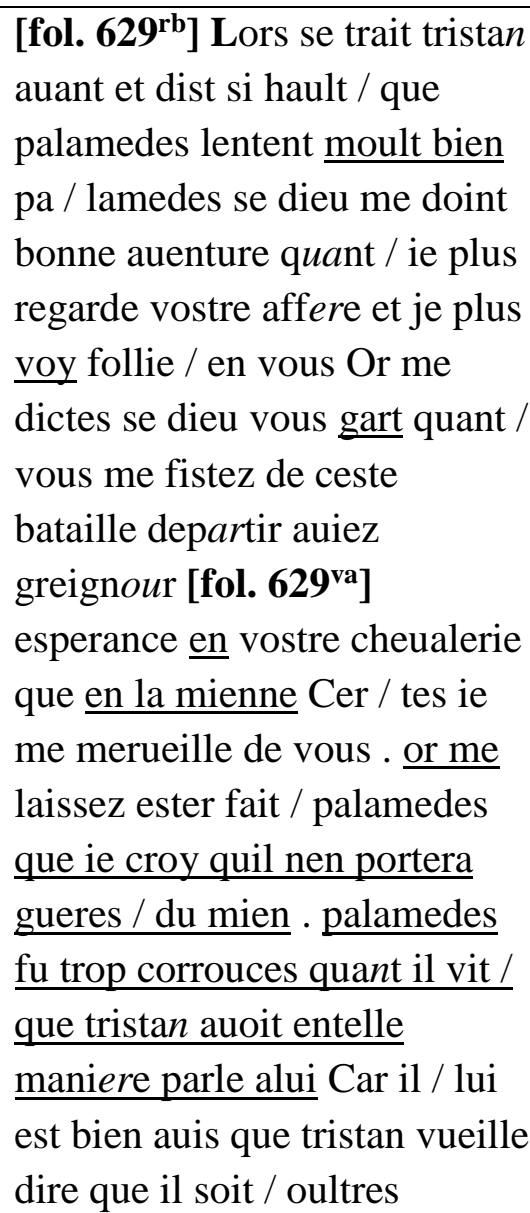 \\
\hline
\end{tabular}

\footnotetext{
${ }^{13}$ Dijon, BM 527, listed by Baumgartner as Version II, forms a set with Chantilly, Bibl. du Château, 648, which preserves Version III. Baumgartner also categorized London, British Library, Additional 5474 and ÖNB 2542 (the "Vulgate" manuscript edited by Ménard et al.) as Version II, but they resemble Version III after Løseth’s §338a (the Agravain interpolation). On the Version III and Version IV sections of Bodmer 164, which Cigni classified as Version II ("Per un riesame," 255), see my forthcoming article in Medioevo Romanzo.
} 
vueille dire quil est oul- / tres

Given the number of readings the Châlons fragment shares with the representative of Version IV, in opposition to other versions, it is highly likely to have been taken from a manuscript that presented Version IV, at least for this part of the text. This brings the total number of known Version IV manuscripts to six:

- Châlons fragment: $\S \S 447-448$;

- Chantilly, Bibliothèque du Château, 645-647 (MS h): complete;

- Cologny, Bodmer 164 (MS X): $\$ 94-171,282$ b, 282d, 390-570 (with lacunae);

- New York, Morgan Library and Museum, M.41 (MS NY): §§219-558;

- Paris, BnF, f. fr. 99 (MS T): complete;

- St Petersburg, Российская национальная библиотека (National Library of Russia), Fr.

F. v. XV. $2\left(\right.$ MS J): $§ \S 118-282$ d. $^{14}$

As Baumgartner noted (Essai d'interprétation, 71-76), Version IV draws chiefly on the text of Version II, but it also presents a number of characteristic interpolations, including Alixandre l'Orphelin, the Tournament of Sorelois, and a distinct version of the Agravain (which is also present in Version III). This compilation, in Baumgartner's opinion, was probably made in the 1330s: the papal appeal to recapture Jerusalem included in the narrative of Tristan's twofold imprisonment perhaps reflects the pressure Pope John XXII was placing on Philippe VI to take the Cross at around this time (idem, 75). The extant manuscripts, however, are rather more recent: MSS $J$ and $X$ date from the late fourteenth century or slightly later, while MSS $T, N Y$ and $h$ can be dated 1463, 1468 and c. 1480 respectively. It is noteworthy that several of these manuscripts were copied in the southern stretches of the öll zone: the Version IV sections of MS $X$ were probably made in Burgundy, MS $N Y$ was decorated in Berry or the Touraine, and MSS $T$ and $h$ were produced respectively in the Limousin and Poitou, for two of the most renowned bibliophiles of the period, Jacques d'Armagnac and Jean du Mas. ${ }^{15}$

Comparison of the Châlons manuscript to other members of Version IV that preserve $\S \S 447$ 448 suggests that the fragment most commonly agrees with the group $N Y$ and $X$, in opposition to $T$ and $h$. Without aiming to be exhaustive, we note:

\footnotetext{
14 The sigla are those of the Ménard edition of Version II, with the exception of the New York manuscript.

15 The language of the Version IV sections of MS X points to the south-east of the oill zone, and the codex as a whole was owned in the fifteenth century by Burgundian nobility. According to the colophon on fol. $775^{\mathrm{v}}$, MS $T$ was copied in 1463 by Michel Gonnot in Crozant (Limousin). It was illustrated by Évrard d'Espinques for Jacques d'Armagnac. MS $h$ was signed by Gilles Gassien, a scribe active in Poitiers, and illustrated $c$. 1480, also by Évrard, at the request of Jean du Mas. On the attributions to Évrard, see François Avril and Nicole Reynaud, Les manuscrits à peintures en France 1440-1520 (Paris: Flammarion, 1993), 165. MS NY, finally, is dated 1468 and was decorated by the Master of the Yale Missel, who worked between Bourges and Tours (ibid., 152-54). Jean de la Moussaye, seigneur de Lorgeril, who is named on fol. $264^{\mathrm{r}}$, may have been its first owner.
} 
- desgarnis de vos armes (fol. $1^{\text {ra }}$; heaumes in $T$ and $h$ );

- je la voulsisse trop mieulx (fol. $1^{\mathrm{ra}}$; amasse in $T$ and $h$ );

- ilz s'entrefierent si durement (fol. $1^{\text {ra }}$; entrehurtent in $T$ and $h$ );

- si commence (nt NY and X) entr'eulx la mellee a cellui point si dure et si felonnesse (fol.

$1^{\mathrm{rb}}$; a cellui point omitted in $T$ and $h$; felonne in $T$ and $h$ );

- ne prisoit il autant nul chevalier comme il faisoit Tristram (fol. $1^{\mathrm{va}}$; nul autant comme in

$T$ and $h$ );

- si viengne li autres aprés a moy (fol. $2^{\mathrm{rb}}$; aprés a moy omitted in $T$ and $h$ );

- Galaad le menoit a sa volenté (fol. $2^{\text {va }}$; la ou il voloit in $T$ and $h$ );

- la demoiselle qui vers la bataille s'en venoit (fol. $2^{\mathrm{vb}}$; vers la bataille omitted in $T$ and $h)$.

Among the witnesses of Version IV, moreover, the Châlons fragment agrees with MS $X$ alone in the following places:

- cestui est le plus fort voirement ([v. le p. f. in $X)$ du monde de chevalier (fol. ${ }^{\text {va.; }}$ chevalier du monde in $N Y, T$ and $h$ );

- jusques a tant que l'en en voye la fin (fol. $2^{\text {ra. }} j$ 'en in $N Y$; second en omitted in $T$ and $h$ ); - pour quoy le demandés vous? (fol. $2^{\text {ra }}$; dictes in $T$; lacuna in $N Y$ and $h$ );

- mais pour l'amour de ce que je ne me pourroye mie (fol. $2^{\text {rb }}$; l'amour de omitted in $T$ and $h$; ce que je voy que vous estes si preus in NY);

- lors s'en va li uns envers l'autre (fol. $2^{\text {va }}$; vont in $N Y$; omitted in $T$ and $h$ );

- je suis tous appareilliés de faire toute vostre voulenté (fol. $2^{\mathrm{vb}}$; toute omitted in $X$;

- faire toute omitted in $T$ and $h$ ); vous en venés orendroit aprés moy (fol. $2^{\mathrm{vb}}$;

presentement for orendroit in $X$; viengne avec(ques) in $T$ and $h$ ).

Our fragment is in agreement with $N Y$ alone on one occasion: la bataille de vostre compaignon et de moy (fol. $2^{\text {va. }}$ de moy et de vostre compaignon in $T, X$ and $h$ ).

The Châlons fragment nonetheless shares several readings, including errors, with MSS $T$ and $h$, and may thus be said to occupy an intermediate position between the two groups:

- after vous vengaste vous auques (fol. $1^{\mathrm{ra}}$ ), omission of de la honte qu'il vous fist (present in $N Y$ and $X$ );

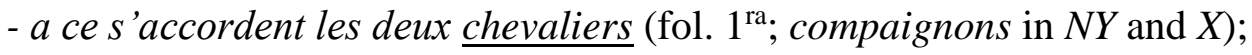

- quant ce vient a l'assembler (fol. $1^{\mathrm{ra}}$; apro(u)chier in $N Y$ and $X$ );

- the common error s'en rit (fol. $1^{\text {va }}$ ) for $s$ 'en seurrit (present in $N Y$ and $X$ );

- de ceste parolle se commence trop plus a courroucier Palamedés ([P. t. p. a c. in $T$ and

h) (fol. $2^{\text {rb }}$; cour (r)ouce in $N Y$ and $\left.X\right)$;

- je suis tout seul, et suis tout prest (fol. $2^{\text {va }}$; omitted in $N Y$ and $X$ );

- quant vous ma bataille $\underline{d u}$ tout (fol. $2^{\text {va; }}$; omitted in $N Y$ and $X$ );

- omission of si la connoist after et Galaad si la regarde (fol. $2^{\mathrm{vb}}$; present in $N Y$ and $X$ ). 
The Châlons text, finally, preserves unique readings in respect of the other Version IV witnesses in the following places:

- vous ne savés mie (fol. $1^{\text {ra }}$; nous ne savons);

- il l'abat a terre, car moult durement fut estonnés (fol. $1^{\mathrm{rb}}$; si in $T, X$ and $h$; tout in $N Y$ );

- after faittes le bien (fol. $1^{\mathrm{rb}}$ ), omission of laissés le;

- il se merveille trop fort (fol. $1^{\text {va, }}$ estrangement in $N Y$ and $X$; omitted in $T$ and $h$ );

- il voit bien que le chevalier ne peut mes en avant (fol. $1^{\mathrm{vb}}$; con $(g)$ noist);

- moult est Palamedés preux et isnel, mais ce que vault? Le chevalerie encontre qui il se combat (fol. $2^{\text {ra }}$; vigoureux; chevalier);

- vous avés perdu un bon traire (fol. $2^{\mathrm{rb}}$; taire); vous vous entremettiés de ceste chose

(fol. $2^{\text {va. }}$ v. v. e. plus de c. c.);

- se traist tantost la demoiselle avers Tristram (fol. $2^{\mathrm{vb}}$; tantost omitted elsewhere; envers).

\section{Linguistic analysis}

The Châlons fragment was written in standard literary Middle French. In terms of the graphical representation of vowels, the following might be noted:

- ai for Standard Medieval French (SMF) a, e.g. visaige (fols $1^{\mathrm{ra}}, 1^{\mathrm{rb}}$ );

- the result of PAUCU is mostly written pou (fols $1^{\mathrm{rb}}, 1^{\mathrm{vb}}, 2^{\mathrm{va}}$, etc.), but po (fol. $1^{\mathrm{va}}$ ) and peu (fol. $1^{\text {va }}$ ) also occur;

- an and en are interchangeable, e.g. encommanc(i)ee (fols $1^{\mathrm{vb}}, 2^{\mathrm{va}}$ ) vs. commence (fols $1^{\mathrm{rb}}, 1^{\mathrm{vb}}, 2^{\mathrm{rb}}$, etc.), vangeray (fol. $1^{\mathrm{ra}}$ ) vs. venge (fol. $1^{\mathrm{ra}}$ );

- $a i$ and $e$ are interchangeable, e.g. mais (fols $1^{\mathrm{ra}}, 1^{\mathrm{rb}}, 1^{\mathrm{va}}$, etc.) vs. mes (fols $1^{\mathrm{rb}}, 2^{\mathrm{va}}$ );

- A + palatal L is written eill, e.g. traveillié(s) (fols $1^{\mathrm{va}}, 2^{\mathrm{rb}}$ ), but note also travaille (fol. $\left.1^{\mathrm{vb}}\right)$;

- ou for SMF o, e.g. voulenté (fols $1^{\mathrm{ra}}, 2^{\mathrm{vb}}$; alongside volenté, fol. $2^{\mathrm{va}}$ ), voulentiers (fols $\left.1^{\mathrm{rb}}, 2^{\mathrm{va}}\right)$, approuche (fol. $1^{\mathrm{vb}}$ ).

In terms of consonants:

- $l$ is often doubled, e.g. cellui (fols $1^{\mathrm{ra}}, 1^{\mathrm{rb}}, 2^{\mathrm{vb}}$, etc.), parolle(s) (fols $1^{\mathrm{va}}, 1^{\mathrm{vb}}, 2^{\mathrm{rb}}$ ), villenie (fol. $1^{\mathrm{rb}}$ );

- ngn occurs in forms of congnoistre and its derivatives, e.g. congnoissent (fol. $1^{\mathrm{ra}}$ ), recongnoist (fols $1^{\mathrm{ra}}, 2^{\mathrm{vb}}$ ), congnoissiés (fol. $1^{\mathrm{ra}}$ ), etc.;

- $t$ is doubled in dittes (fols $\left.2^{\mathrm{ra}}, 2^{\mathrm{rb}}, 2^{\mathrm{vb}}\right)$, faittes (fols $1^{\mathrm{rb}}, 1^{\mathrm{va}}, 2^{\mathrm{ra}}$, etc.), ottroye (fol. $1^{\mathrm{ra}}$ ); 
- $s$ may be represented by $s c$ (e.g. sçay fols $1^{\text {va }}, 2^{\text {va. }}$ scet fol. $1^{\text {va }}$ ), and in final position by $x$ (e.g. courroux fol. $1^{\mathrm{ra}}$; eulx fols $1^{\mathrm{rb}}, 2^{\mathrm{va}}, 2^{\mathrm{vb}}$; preux fols $1^{\mathrm{vb}}, 2^{\mathrm{ra}}$ ) and occasionally by $z$ (e.g. je fiz fol. $2^{\mathrm{vb}}$; nulz fols $1^{\mathrm{rb}}, 2^{\mathrm{ra}}$; pareilz fol. $1^{\mathrm{rb}}$ );

- $g$ represents $j$ in vengastes (fol. $1^{\mathrm{ra}}$ ), vengai (fol. $1^{\mathrm{ra}}$ );

- (pseudo-)etymological letters are re-introduced in corps (fol. $1^{\mathrm{ra}}$ ), oultrance (fols $2^{\mathrm{ra}}$,

$2^{\mathrm{va}}$ ), advis (fol. $1^{\mathrm{rb}}$ ), dessoubs (fols $1^{\mathrm{ra}}, 1^{\mathrm{vb}}$ ), chevaulx (fol. $\left.1^{\mathrm{ra}}\right)$, hault $(e)$ (fols $\left.1^{\mathrm{va}}, 1^{\mathrm{vb}}, 2^{\mathrm{ra}}\right)$, sault (fol. $2^{\text {rb }}$ ), etc.

Turning to morphology and syntax, we observe the following:

- flexional $-s$ is often added to masc.nom.sing. adjectives and past participles, e.g. il avoit esté abatus (fol. $1^{\mathrm{ra}}$ ), Claudin fut estourdis (fol. $1^{\mathrm{rb}}$ ), il est desarmés (fol. $1^{\mathrm{rb}}$ );

- analogical fem. forms of tel and quel ending in -e, e.g. telle (fols $1^{\mathrm{rb}}, 1^{\mathrm{vb}}, 2^{\mathrm{ra}}$, etc.), quelle (fol. $1^{\mathrm{va}}$ );

- the 3.pers.pl. subject pronoun is ilz;

- the 3.pers.sing. indirect obj. pronoun is always lui;

- an $s$ is added to 1.pers.sing. forms of the present tense in suis (fols $1^{\mathrm{va}}, 1^{\mathrm{vb}}, 2^{\mathrm{ra}}$, etc.) and viens (fol. $2^{\mathrm{vb}}$ );

- the 1.pers.pl. verb indicative ending is consistently -ons;

- the 2.pers.pl. verb ending preferred by the scribe is -és, but -ez occurs in laissiez (fol. $\left.2^{\mathrm{ra}}\right)$

- genitive expressions may lack a preposition, e.g. l'escu Claudin (fol. $1^{\mathrm{ra}}$ ), la bataille Palamedés (fol. $1^{\mathrm{rb}}$ );

- past participles agree with a preceding direct object, e.g. la grant force qu'il a trouvee (fol. $1^{\text {va }}$.

While such forms as visaige and pou would at least be consistent with production in Champagne, or in the east or south-east of the oill zone, they were employed sufficiently widely in the fourteenth and fifteenth centuries to frustrate any twenty-first-century attempt at localization on the basis of the scribe's language. The scripta does confirm, however, that the manuscript was copied at the tail end of the fourteenth century, or (more likely) in the early part of the fifteenth.

It may not be possible to localize the Châlons fragment with any degree of precision, but it nonetheless makes an important contribution to our understanding of how the prose Tristan circulated in the later Middle Ages. The version known as Version IV can no longer be considered an obscure fourteenth-century reworking of the text that has only survived because the most avid late-fifteenth-century book collectors had encyclopaedic interests in Arthuriana; the date of the Châlons fragment and that of the closely related MS $X$ suggest that Version IV circulated more widely during the late fourteenth or early fifteenth century than previously thought. More significantly, however, the Châlons fragment reminds us that a witness should not be presumed to pertain to the most common version of a text before it has been collated against 
copies of other versions. Further consideration of manuscripts previously classified as Version II of the prose Tristan - and of fragments in particular - may yet prove fruitful.

\section{Transcription}

In the transcription that follows, I have regularized word separation, capitalization and punctuation according to modern usage. I distinguish the letters $u$ from $v$ and $i$ from $j$, add an accent to final tonic $-e$ and $-e s$ in polysyllables, and use a dieresis where necessary. Expansions of abbreviations appear in italic type. Decorated initials appear in bold type. Where the text is illegible due to wear or other damage to the parchment, conjectural readings are supplied in square brackets on the basis of the other Version IV witnesses.

[... “il ne seroit pas bien qu'il vous tro-] [fol. $\left.\mathbf{1}^{\text {ra }}\right]$ [v]ass[e]nt a pié ne desgarnis de vos armes."

"Voirs est," ce dist Tristram.

"Sire," fait Palamedés, "Montés! Vous ne savés mie la voulenté des chevaliers."

"Bien me plaist," ce dist Tristram.

Il monte adoncques et aussi fait Palamedés. Quant les trois chevaliers les voyent, ilz s'arrest[en]t, car bien congnoissent delivrement que ce sont chevaliers errans, et Claudin si dist a Galaad,

“Sire, s'il vous plaist, je vueil la [j]ouste de l'un de ces deux chevaliers, car ilz ne sont illecques arrestés se pour joust[er] non."

"Et vous l'aiés," ce dist Galaad, "et non pourquant je la voulsisse trop mieulx por $\mathrm{m}[\mathrm{oy}] . "$

Angenés demande l'autre jouste, et Galaad lui ottroye. Et lors se mettent avant les deux chevaliers et escrient aus autres [de]ux,

15 "Seigneurs, vous plaist il a jouster?"

Tristram, qui recongnoist l'escu Claudin, tout [mai]ntenant le moustre a Palamedés, et lui [dist],

"Sire, congnoissiés vous cellui escu que vous veés la?"

Palamedés qui le regarde le congnoist et dist,

20 "Voirement le congnois je bien. Je ne le vy mes puis qu'il me fist honte et courroux durement. Il est mest[ier] que je venge encore nuit ceste honte. Je vueil [av]oir la jouste de lui."

"Ce ne vueil je mie," ce dist Tristram, "mais je la vueil avoir et vous ayés l'autre, car de cellui vous vengastes vous auques et le menastes pres jusques a outrance. Mais je ne

25 m'en vangay point, et pour ce m'en vangeray je ores, se je puis."

A [ce] s'accordent les deux chevaliers. Tristram laisse courre a Claudin, qui avant venoit, et [cellui 1]ui revient autressi tant comme il peut du cheval traire. Et quant ce vient a l'ass[em]bler, ilz s'entrefierent si durement qu'ilz cheïrent a la terre, les 
chevaulx dessus les corp[s]. Tristram se relieve tantost, si comme cellui qui n'avoit nul autre mal que du chëoir qu'il avoit fait, et si est trop durement courrouciés de ce qu'il avoit esté abatus deux fois par cellui chevalier. Il n'atant mie tant que cellui chevalier soit redreciés du tout, ainçois lui court sus et le prent parmi le heaume et le tire si fort qu'il lui [ront] les las et lui arrache hors de la teste si [fort] qu'il lui [ront] du front le cuir, et du visaige aussi, si que le sang lui court dessus [fol. $\mathbf{1}^{\mathbf{r b}}$ ] le visaige et il gette le heaume loing de lui. Et Claudin fut estourdis si durement qu'il l'abat a ter[re, ca]r moult durement fut estonnés. [Et Pala]medés, qui ot laissié a Angenés courre, le fiert si asprement que il l'abat a terre et lui fist une grant playe au costé senestre. Quant il l'ot abatu, il s'en va oultre pour parfaire son poindre, et puis descend et baille son cheval a son escuier a garder. Quant il a ce fait, il met la main a l'espee et s'en va moult grant erre vers Angenés. Et cellui qui ja estoit [re]levés, honteux trop durement, s'appareille de la bataille. Ainsi commencent la bataille entr'eulx deux. Tristram a la sienne bataille definee en pou d'eure, car puis que Claudin voit qu'il avoit son heaume perdu, il se commence a retraire arrieres et bien moustre tout appertement qu'il ne pourroit en lui avoir defense. Qua[nt] Galaad voit ceste chose, il descent et vient a Tristram et lui dist,

"Sire chevalier, vous fa[itt]es villenie, qui ce che[valier] alés en telle maniere envaïssant. Il m'est advis que, puis qu'il est sans heaume, il est desarmés, et encontre homme desarmé ne devriés vous mettre la main en nulle maniere. Mais faittes le bien et vous prenés a moy!"

"Certes, voulentiers!" ce dist Tristram.

50 Lors laisse Claudin et s'en va vers Galaad le petit pas et cellui lui vient autressi. Si commence entr'eulx la mellee a cellui point si dure et si felonnesse que nulz ${ }^{16}$ qui ne les veïst adoncques qui ne deïst que ilz ne feüssent bons chevaliers [et preux] et de grant affaire. En telle maniere comme je vous conte se combatent les deux chevaliers; auques sont pareilz de [bon]té, mes toutesvoies il est advis a ceulx qui par dehors estoient que Galaad en avoit le plus bel. Ainsi ne va mie la bataille Palamedés:

Palamedés a ja tel atourné a Angenés par force d'armes qu'il ne pense jamés faire autre bataille. Et quant Palamedés voit qu'il l'a si mis au dessoubs que occire le peut s'il veult, il se trait a [deux pas en] arrieres et commence a penser et a regarder la bataille de Tristam, et lui dist,

60 "Sire, laissiés moy ceste bataille et vous alés combatre a mon compaignon! Il ne durera ja encontre vous, ne cellui a [fol. $\mathbf{1}^{\text {va }}$ ] qui vous vous combatés n'avra ja duree encontre moy."

Quant Tristram, qui a c[ellu]i point estoit si forsenés et si traveilliés en[tent] les parolles de Palamedés, il s'en rit et se trait un peu arrieres. Galaad si se retrait de la

65 sienne partie et tout maintenant que monseigneur Tristram se fut retrais, sachiés qu'il se merveille trop fort qui peut estre le chevalier qui encontre lui se combat, car a la grant force qu'il a trouvee en lui et a la grant visteté dist il bien a soy mesmes que

\footnotetext{
${ }^{16} \mathrm{MS}$ nulz deuls.
} 
cestui est le plus fort voirement du monde de chevalier qu'il trouvast oncques mes fors Tristram. Et par la grant force qu'il a trouvee en cestui dist il bien tout appertement que ce fut Tristram. Mais l'en lui avoit fait entendant que Tristram estoit emprisonnés ou royaume de Sorelois, et pour la sienne delivrance pensoit il a aler celle part, car de haulte chevalerie ne prisoit il autant nul chevalier comme il faisoit Tristram. Et aucunes fois, quant aucun lui demandoit qui estoit le meilleur chevalier du monde et qu'il plus prisoit de chevalerie, [il disoit, $]^{17}$

75 "Je ne sçay ores nul si preudomme comme est Tristram de ceulx a qui je me suis combatus."

Ceste parolle avoit ja ditte maintes fois Galaad de Tristram, et a ceste fois d'orendroit, quant il se combat a lui, l'eüst il recongneü assés tost, mais pour ce que l'en lui avoit dit qu'il estoit emprisonnés en Sorelois ne povoit il cuidier en nulle maniere que ce feüst il. Quant ilz se furent un po retrait, ainsi comme je vous ay dit, Palamedés, qui bien cuidoit que Tristram fust si traveilliés qu'il ne peüst en avant, se met avant et dist,

"Sire chevalier, gardés vous de moy! Je vous appelle de la bataille."

"Certes," ce dist Galaad, "vous lui faittes grant honte, se il recongnoistre le scet, car

85 vous lui moustrés qu'il ne se peut envers moy defendre, et aprés ce faittes semblant qu'il soit pires chevalier de vous et que vous avés greigneur esperance en vostre chevalerie que en la sienne. Or regardés quelle honneur vous lui faittes!"

Palamedés est trop honteux quant il entent ceste parolle; il ne scet que il doye dire [fol. $\mathbf{1}^{\mathbf{v b}}$ ] ne respondre.

90 "Vassal," dist il a Galaad, "or sachiés que je ne pensoye mie a ce que vous pensés. Vous l'avés dit et non pour autre [cho]se fors pour ce que vous vous delivrés de moy par parolles, mais non ferés! Combatre vous convient a moy!"

"Certes," ce dist Galaad, "se je me combatoye a vous, et je laisse mon [com]paignon j'avray moult meilleur avan[tage] que je n'avoye devant, car je voy tout appertement

95 que vous n'estes mie si bon cheval[ier] comme il est, ne si fort d'assés, et pour ce [me] combatray je a vous plus seürement. Et non pourquant ce n'est mie courtoisie de changier moy bataille devant icelle heure que l'en veïst le meilleur de nous deux [et] le plus fort."

A parolle que Galaad dit ne respond nulle riens Palamedés ${ }^{18}$, ain[çois] s'en va le 100 grant pas vers lui, l'escu joint dessus son pis, l'espee droite contremont. [Et] approuche de lui, et lui donne un cop [si] fort ${ }^{19}$ dessus le heaume que, tout soit il bon chevalier et ait le heaume assés fort, si l'e $[\mathrm{m}]$ pire il et le malmet et le fait auques [em]brouchier. Mais cellui se redrece au plus tost qu'il peut et se retrait un pou arrieres, et dit bien a soy mesmes que de grant force et de grant povoir est cellui qui tel cop lui a donné, car

\footnotetext{
${ }^{17}$ Omitted.

${ }^{18}$ MS Palamedemedes.

${ }^{19} \mathrm{MS} f o<n>t$.
} 
105 moult grant piece a qu'il ne le receüt autretel. Et non pourquant, tout soit il fort et preux et de haulte prouesse plains, si dist lors que se il n'abat son orgueil, il ne se tient pas a chevalier. Lors lui commence a courre sus moult asprement et a donner grans cops a destre et a senestre. Moult s'efforce durement et se travaille de tout son povoir de mettre le au dessoubs et bien voit que autrement ne le peut il mie fai[re] a ce que 110 Palamedés est preux et vistes. Q[uant] Tristram voit que la bataille est en telle maniere encommancee, il se tourne vers Angenés et lui court sus, l'espee traite, et le maine tout maintenant a ce qu'il n'a povoir ne force qu'il se puisse envers lui tenir ne deffendre. Quant Tristram voit ceste chose, il voit bien que le chevalier ne peut mes en avant, il le laisse tout en paix delés un arbre et [s'en] vient a la bataille que les aultres deux

115 chevaliers faisoyent et voit Galaad qui se [com]- [fol. $2^{\text {ra }}$ ] batoit moult fort, et Palamedés autressi. Ilz feroient ambedeux moult fort les uns dessus les autres, si menu et si souvent et de telle force que nulz ne les veïst adoncques, pour tant qu'il congneüst bons chevalier, que bien ne deüst dire que voirement ${ }^{20}$ estoit il preux et hardis. Quant Tristram a moult grant piece regardé cellui estrif et la grant prousse de l'un et de 120 1'autre, il dist a soy mesmes,

"Ha, sire Dieux, moult est Palamedés preux et isnel, mais ce que vault? Le chevalier $^{21}$ encontre qui il se combat est assés meilleur chevalier, ce voy je bien tout appertement. Ceste bataille si n'est mie si bien partie comme je voulsisse, car li uns est plus fors que li autres."

125 La ou il parloit en telle maniere, il regarde et voit que Galaad commença a prendre terre dessus Palamedés au tranchant de l'espee, une heure arriere et autre avant, ou ça ou la, si ques Tristram s'apparçoit bien que au derrenier ne pourroit pas Palamedés durer encontre lui.

Lors se trait Tristram avant et dist si hault que Palamedés l'entent moult bien,

130 "Palamedés, se Dieux me doint bonne avanture, quant je plus regarde vostre affaire et je plus voy folie en vous. Or me dittes, se Dieux vous gart, quant vous de ceste bataille me feïstes departir, aviés vous greigneur e[spera]nce en vostre chevalerie que en la mie[nne]?"

"[Cert]es, je me merveille de vous. Or me [laissiés ester]," ce dist Palamedés, "que je 135 croy qu'il [n'e]mportera gueres du mien."

Palamedés fut trop courrouciés quant il vist que Tristram avoit en telle maniere parlé a lui, car il lui est bien avis que Tristram vueille dire qu'il est oultrés, et pour ce lui respond il une autre fois et dit,

"Vassal, puisqu'il est ainsi que vous la bataille de ce chevalier me laissastes, laissiez 140 sur moy toute ceste besoingne jusques a tant que l'en en voye la fin."

"Ce ne feray je mie," ce dist Tristram, "car je vueil avoir ma bataille de rechief!"

\footnotetext{
${ }^{20}$ Due to eyeskip, the MS omits sont il boin cevalier et de haut afaire. Saciés que Palamidés mostroit bien que voirement.

${ }^{21}$ MS cheualerie.
} 
"Beaux seigneurs," ce dist Galaad, "estes vous chevaliers errans?"

"Oïl, certes," ce dist Tristram, "pour quoy le demandés vous?"

"Pour ce," dist Galaad, "que vous ne faittes mie comme chevalier errant, car quant ilz se combatent a autres, ilz ne doivent pas faire ce que vous alés orendroit faisant. Vous vous combatistes premiere- [fol. $2^{\text {rb }}$ ] ment a moy tant que vous fustes si [durement] traveillié comme je vi, et lors laissastes vous adoncques la bataille, et lors vint un autre compaignon combatre a moy. Et orendroit, quant il est traveillié et vous estes reposé, si vous voulés combatre a moy, qui traveilliés suis par avanture plus que vous ne cuidiés.

150 Voulés vous doncques dire que ce soit maniere de preudomme? Certes, nanil!"

Quant Tristram entent ceste parolle, il en est honteux trop durement. Si respond, "Certes, sire, vous en avés parlé comme amesuré chevalier, et nous avons moult mespris encontre vous. Or me dittes que vous voulés que nous facions."

"Certes," dist Galaad, "je vous diray que vous povés faire. Tant congnois je bien de 155 vous deux que vous estes ambedeux de haulte prouesse plains, mais pour l'amour de ce que je ne me pourroye mie combatre encontre vous deux en telle maniere comme vous avés encommancié, car li uns se veult reposer aprés l'autre. Or faittes une autre chose que je vous diray: cellui de vous deux qui plus se fie en soy, si se viengne premierement combatre a moy, et puis que je l'auray mené jusques a oultrance, si 160 viengne li autres aprés a moy."

De ceste parolle se commence trop plus a courroucier Palamedés que Tristram ne fait. Si parolle adoncques moult hardiement, et dist,

"Sire vassal, cuidiés vous que vous nous puissiés mener jusques a oultrance?"

"Certes, sire," ce dist Galaad, "vous me ferés ja dire une parolle que je ne deüsse pas

165 dire en nulle maniere, car nul chevalier ne se doit louer. Je congnois bien que vous estes ambedeux bons chevaliers, mais se Dieux me sault, encores [n'a]y [je pas trou]vee en vous si haulte prouesse de chevaler[ie] que, se avanture me menoit a ce que je me de[üsse] a vous combatre jusques a oultrance, je vous cuideroye bien par force d'armes mener jusques la ou vous ne vouldriés pas aler, ne mes que li uns venist aprés l'autre."

"Sire chevalier," ce dist Palamedés, "se Dieux me gart, vous avés perdu un bon taire $^{22}$ comme a cestui poi[nt]. Et puis que je cognois en vous si [folle sur]cuidance comme je voy, ce[rtes je ne laisse]roye pour la meilleur c[ité que li rois Artus] [fol. $\mathbf{2}^{\text {va }}$ ] [ait] que je ne me combatisse orendroit a vous. Et se avanture ne m' [e]st trop durement contraire en cestui jour d'ui, vous cuide je tant donner a faire avant que vous m'aiés mené jusques a oultrance que vous n'avrés ja talent que nul autre viengne dessus vous aprés moy."

"Certes," ce dist Galaad, "[a] vous ne me combatray je mie voulentiers premierement que la bataille de vostre compaignon et de moy [soit] menee a fin. Vous estes bon 180 chevalier, ce sçay je bien, mais encores est il meilleur, je le vous di. Et pour ce me

\footnotetext{
${ }^{22}$ MS traire.
} 
v[eui]l je premiers combatre a lui, et puis a vous, se Dieux me laisse a sauveté departir de lui."

"Certes," ce dist Palamedés, "ce ne vault neant! A moy vous convient a combatre!" "Encores vous feray je greigneur avantage," ce dist Galaad, "se vous voulés."

185 "Et quel?" ce dist Palamedés.

"Or sachiés que je suis tout seul, et suis tout prest que je me comb[ate] a vous deux. Et se vous par force d'armes me povés mettre au dessoubz, me[tés m'i]!”

De ceste parolle est Tristram tout esbahi. Lors se met avant et dist a Palamedés, "Laissiés [moy] ma bataille! Je ne vueil [que vous vous] entremettiés de ceste chose. Le chevalier est de grant affaire, ce [voy je] bien, et pour ce vueil je ceste preuve [du tout] dessus moy."

"Sire," ce dist Palamedés, "quant vous ma bataille du tout me [tolés], je me souffreray atant. Or y parra que vous ferés!"

Lors se met avant Tristan, l'espee toute nue en la main, et dist a Galaad,

195 "Sire, puis qu'il est ainsi avenu que nous sommes [venus] ensemble, or recommençons nostre bataille. Si verrons a qui Die[ux] en donra l'onneur."

"Certes," fait Gala[ad, "ce me] plest bien."

[Et] lors s'en va li uns envers l'autre et commencent la mellee si grant et si mer[veilleuse que nul] ne veïst adoncques la grant prouesse d'eulx deux qui bien ne 200 deüst dire que voirement estoient ilz ambedeux pleins de grant prouesse. Mais a la fin ne p[ue]t durer Tristram, car Galaad le menoit a sa volenté, or ça, or la, si que en pou d'[eure] l'eüst il mené [jusques] a oultrance [se la batai]lle eüst gue[res duré longuement. Mes ainsi comme ilz se comb] atoient en telle maniere, [fol. $\mathbf{2}^{\mathbf{v b}}$ ] atant es vous dessus eulx venir une demoiselle montee dessus un palefroy noir. Et s'aucun me demandoit qui la demoiselle estoit, je diroye que c'estoit la demoiselle mesmes par qui Galaad avoit esté delivrés des mains Breüx sans Pitié par la prouesse Angenés, ainsi comme nous vous avons conté ça arrieres. ${ }^{23}$ Et pour la bonté que la demoiselle avoit fait a l'un et a l'autre, lui avoit promis Galaad un don tel comme elle lui demanderoit, pour qu'il lui peüst donner en aucune maniere. La demoiselle qui vers la bataille s'en 210 venoit tant comme elle povoit du cheval traire toute l'ambleüre, quant elle vist Galaad, qui encontre Tristram se combatoit, elle le recongnoist delivrement. Et pour ce se met elle avant tout seürement, et dist,

"Arrestés vous, seigneurs chevaliers, tant que j'aye parlé a vous!"

Et Galaad si la regarde et dist,

215 "Demoiselle, que vous plaist? Dittes le moy, car bien sachiés que je suis tous appareilliés de faire toute vostre voulenté a mon povoir."

"Grant mercis, sire," dist elle, "car pour l'esperance de ceste chose viens je ceste part. Vous savés bien que vous me promeïstes un don."

“Certes," fait il, "vous dittes voir, je le vous promis et je le doy bien fa[ire, c]ar je

${ }^{23}$ MS <ar > ca arrieres. 

avecques moy, car bien sachiés tout vraiement que j'ay grant mestier de vostre secours."

"Ha! demoiselle," dist il, "pour Dieu, mercy! Au moins me souffrés tant que je soye

"Vous savés bien," fait elle, "que je fiz pour vous et que vous me promeïstes, et pour celle bonté devés vous toutes besoingnes laissier pour la moye. Pour quoy je vueil que vous laissiés ceste et vous en venés orendroit apré[s] moy."

"Ha! demoiselle," dist il, "pour Dieu, mercy! Je ne pourroye ce faire, se ce chevalier a qui je me combat ne m'en donnoit con[gié], car si legierement ne me pourroye je pas partir de lui [et devant] que l'un de nous deux eüst [1'onneur de ceste bataille." Adoncques se] traist tantost la demoiselle avers Tristram et [...]

\section{Bibliography}

Avril, François, and Nicole Reynaud. Les manuscrits à peintures en France 1440-1520. Paris: Flammarion, 1993.

Barthélemy, Édouard de, ed. "Inventaire du mobilier de l'église de Notre-Dame-en-Vaux, de Châlons-sur-Marne, dressé en 1526.” Revue des Sociétés savantes des départements n.s. 2 (1880): 268-81.

Baumgartner, Emmanuèle. Le «Tristan en prose» : essai d'interprétation d'un roman médiéval. Geneva: Droz, 1975.

Benedetti, Roberto. "Un frammento del Roman de Tristan en prose: fra tradizione toscana e tradizione veneta (Udine, Archivio di Stato, fr. 110)." Studi mediolatini e volgari 49 (2003): 47-69.

Bennett, Philip. "L'importance des fragments pour l'établissement des traditions manuscrites : une étude du fragment du Tristan en prose d'Exeter.” Romania 95 (1974): 84-104.

Blanchard, Joël, ed. Le Roman de Tristan en prose : les deux captivités de Tristan. Paris: Klincksieck, 1976.

Bogdanow, Fanni. "Un nouveau fragment du roman de Tristan en prose.” Romania 80 (1959): 516-522

Buirette de Verrierres, Claude-Rémi. Annales historiques de la ville et comté-pairie de Châlonssur-Marne. Châlons-en-Champagne: Seneuse, 1788. 
Carné, Damien de, and Yan Greub. "Le fragment de Nancy du Tristan en prose." Romania 131 (2013): 179-200.

Chênerie, Marie-Luce. "Étude et édition des fragments du Tristan en prose de Toulouse." Bulletin bibliographique de la Société internationale arthurienne 50 (1998): 231-264.

Cigni, Fabrizio. "Per un riesame della tradizione del Tristan in prosa, con nuove osservazioni sul ms. Paris, BnF, fr. 756-757.” In Culture, livelli di cultura e ambienti nel Medioevo occidentale: Atti del IX Convegno della Società Italiana di Filologia Romanza (S.I.F.R.), Bologna, 5-8 ottobre 2009, edited by Francesco Benozzo, 247-78. Rome: Aracne, 2012.

Curtis, Renée L., ed. Le Roman de Tristan en prose. 3 vols. Munich: Max Hueber, 1963; Leiden: Brill, 1976; Cambridge: Brewer, 1985.

Dionisotti, A. C. "On Fragments in Classical Scholarship." In Collecting Fragments = Fragmente sammeln, edited by Glenn W. Most, 1-33. Göttingen: Vandenhoeck \& Ruprecht, 1997.

Hermant, Maxence. "Enlumineurs et commanditaires à Châlons et à Reims au XVe siècle." In Très riches heures de Champagne : l'enluminure en Champagne à la fin du moyen âge, edited by François Avril, Maxence Hermant, and Françoise Bibolet, 59-75. Paris: Hazan, 2007.

Longobardi, Monica. "Dall'Archivio di Stato di Bologna alla Biblioteca Comunale dell'Archiginnasio: resti del Tristan en prose e de Les Prophécies de Merlin." Studi mediolatini e volgari 39 (1993): 57-103.

Löseth, E. Le Roman de Tristan, le Roman de Palamède et la Compilation de Rusticien de Pise : analyse critique d'après les manuscrits de Paris. Paris: Bouillon, 1891.

Ménard, Philippe, et al., eds. Le Roman de Tristan en prose. 9 vols. Geneva: Droz, 1987-1997.

Ménard, Philippe, et al., eds. Le Roman de Tristan en prose : version du manuscrit fr. 757 de la Bibliothèque nationale de Paris. 5 vols. Geneva: Slatkine, 1997-2007.

Nixon, Terry. "Catalogue of Manuscripts." In Les Manuscrits de Chrétien de Troyes = The Manuscripts of Chrétien de Troyes, edited by Keith Busby, Terry Nixon, Alison Stones \& Lori Walters, vol. II, 1-85. Amsterdam: Rodopi, 1993.

Pelaez, Mario. "Un frammento del romanzo francese in prosa di Tristano." Studi medievali 2 (1929): 198-204.

Peri, Hiram. "Épisodes inédits du Roman de Tristan (manuscrit de Jérusalem) avec deux nouveaux lais de Tristan." Scripta Hierosolymitana 2 (1955): 1-24. 
Radaelli, Anna. "Il testo del frammento Vb2 del Roman de Tristan en prose (Biblioteca Apostolica Vaticana, Vat. Lat. 14740).” Studi mediolatini e volgari 50 (2004): 185-223.

Samaran, Charles. "Fragments de manuscrits." Romania 76 (1955): 240-43.

Séguy, Jean. "Fragments mutilés du Roman de Tristan en prose." Bulletin bibliographique de la Société internationale arthurienne 5 (1953): 85-95.

Stones, Alison, "Chronological and Geographical Distribution of Lancelot-Grail Manuscripts." Lancelot-Graal Project. 2010. Accessed May 8, 2015. http://www.lancelotproject.pitt.edu/LG-web/Arthur-LG-ChronGeog.html.

Stones, Alison. "The Earliest Illustrated Prose Lancelot Manuscript." Reading Medieval Studies 3 (1977): 3-44.

Vielliard, Françoise. "Les fragments du Tristan en prose de Poitiers : Arch. départ. de la Vienne, pièce 13." In Des Tristan en vers au Tristan en prose : hommage à Emmanuèle Baumgartner, edited by Laurence Harf-Lancner, Laurence Mathey-Maille, and Bénédicte Milland-Bove, 395-414. Paris: Champion, 2009.

Vielliard, Françoise. Manuscrits français du moyen âge. Cologny: Fondation Martin Bodmer, 1975.

Zingerle, Wolfram von. "Ein Tristan-Fragment in Tirol.” Romanische Forschungen 10 (1899): 475-486. 